University of Louisville

ThinkIR: The University of Louisville's Institutional Repository

Electronic Theses and Dissertations

$5-2014$

\title{
Undoings : reversals and dissolutions of binaries in the narrative films of Peter Greenaway.
}

Kristina Sue Bohleber Groves 1978-

University of Louisville

Follow this and additional works at: https://ir.library.louisville.edu/etd

Part of the English Language and Literature Commons

\section{Recommended Citation}

Groves, Kristina Sue Bohleber 1978-, "Undoings : reversals and dissolutions of binaries in the narrative films of Peter Greenaway." (2014). Electronic Theses and Dissertations. Paper 541.

https://doi.org/10.18297/etd/541

This Master's Thesis is brought to you for free and open access by ThinkIR: The University of Louisville's Institutional Repository. It has been accepted for inclusion in Electronic Theses and Dissertations by an authorized administrator of ThinkIR: The University of Louisville's Institutional Repository. This title appears here courtesy of the author, who has retained all other copyrights. For more information, please contact thinkir@louisville.edu. 


\title{
UNDOINGS: REVERSALS AND DISSOLUTIONS OF BINARIES IN THE
} NARRATIVE FILMS OF PETER GREENAWAY

\author{
By \\ Kristina Sue Bohleber Groves \\ B.A., University of Southern Indiana, 2001

\begin{abstract}
A Thesis
Submitted to the Faculty of the

College of Arts and Sciences of the University of Louisville in Partial Fulfillment of the Requirements for the Degree of
\end{abstract} \\ Master of Arts \\ Department of English \\ University of Louisville \\ Louisville, Kentucky
}

May 2014 

UNDOINGS: REVERSALS AND DISSOLUTIONS OF BINARIES IN THE NARRATIVE FILMS OF PETER GREENAWAY

\author{
By
}

Kristina Sue Bohleber Groves

B.A., University of Southern Indiana, 2001

A Thesis Approved on

April 17, 2014

by the following Thesis Committee:

Dr. Thomas B. Byers

Dr. Karen L. Kopelson

Dr. L. Andrew Cooper 


\section{DEDICATION}

This thesis is dedicated to my son

Daniel A. Groves 


\section{ACKNOWLEDGEMENTS}

I would like to thank my director, Dr. Thomas Byers, for guiding me through this process. I would also like to thank the other committee members, Dr. Karen Kopelson, and Dr. Andrew Cooper for their patience and guidance. Thank you also to my husband, Steven, for his understanding and support for the duration of my time at the University of Louisville. Thanks to my son, Daniel, as well for understanding why I could not always be at his events and tuck him into bed every night. Also, thank you to my parents, Steven and Vicki Bohleber, and to my extended family for helping with the logistics of this endeavor and for their constant support. Thank you to my friends who have lent a caring ear, especially Amanda Salem, who I could always count on to respond positively. Many thanks, also, to Eric D. Braysmith at the University of Southern Indiana; I first discovered the world of Peter Greenaway when he showed A Zed and Two Noughts in his film class in 2001. 


\section{ABSTRACT \\ UNDOINGS: REVERSALS AND DISSOLUTIONS OF BINARIES IN THE NARRATIVE FILMS OF PETER GREENAWAY \\ Kristina S. Bohleber Groves}

April 17, 2014

In this thesis, discussed and analyzed are the narrative films of British film director Peter Greenaway through lenses of queer theory, feminism, and theories of the monstrous to investigate Greenaway's notion of the Other in his films. Nearly all his films include a "nonstandard" Othering of characters, a breaking down of societal binaries, as well as crossing the line of what is taboo in our society. This Othering forces viewers to reevaluate their own subjectivity, and to evaluate which groups they see themselves as a part of. In creating fantastic worlds in which the characters do not function within the same boundaries as the "real world," Greenaway deconstructs and restructures boundaries within the minds of his viewers. In reflecting our own images in Greenaway's Others, we can begin to understand, encounter, and face external Others, as well as the Others that lurk within our own psyches. 


\section{TABLE OF CONTENTS}

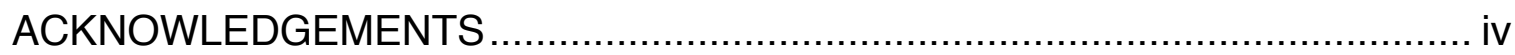

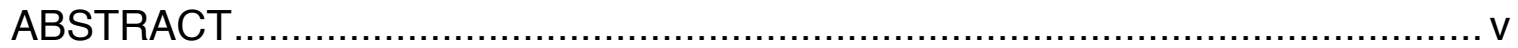

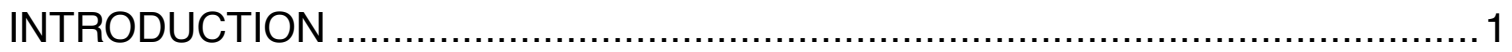

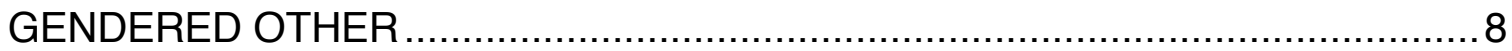

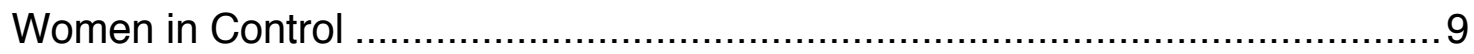

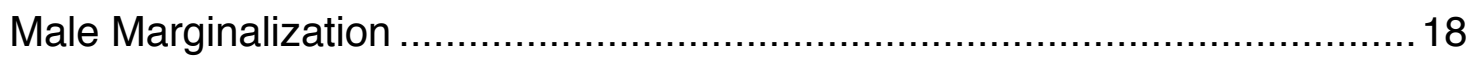

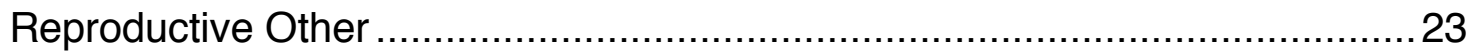

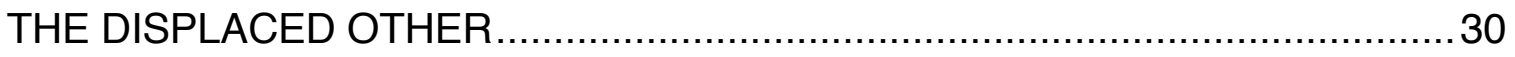

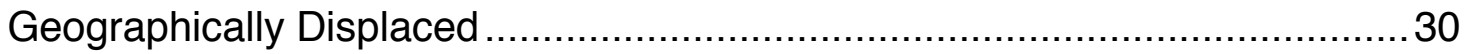

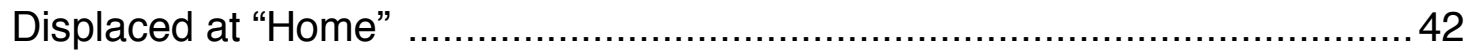

THE MONSTROUS, MUTANT, OR MUTILATED OTHER …........................... 48

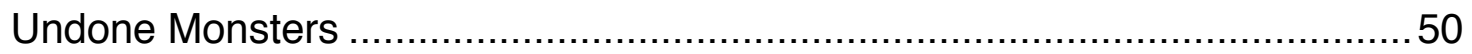

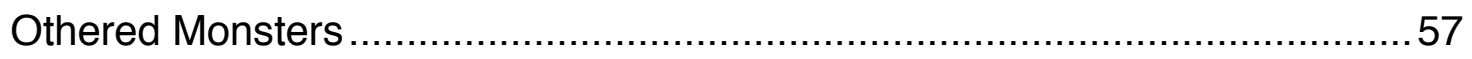

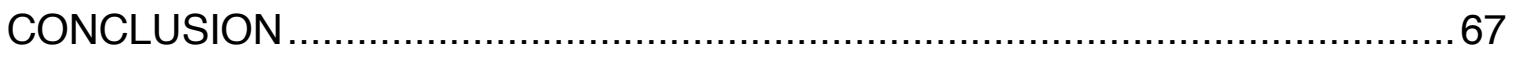

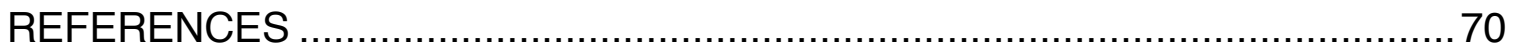

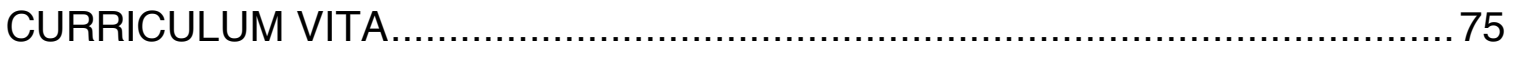




\section{CHAPTER 1: INTRODUCTION}

Near the end of their 1998 essay "Sex in Public," Lauren Berlant and Michael Warner share a story about "erotic vomiting" in a leather bar (206). The bar patrons' response to this event, however, is not what one might expect. As a male partner feeds a (straight) man an overabundance of food, the initially horrified crowd becomes "transfixed" and finally erupts into cheers as the man vomits. The authors say they "have never seen such a display of trust and violation" (207). The act witnessed is not as immediately or obviously sexual as other acts in the bar, but the authors conclude the act was indeed a "nonstandard intimacy" outside of the heteronormativity perpetuated by society. The man, though seemingly externally meeting the requirements of the "normal," was initially Othered through his feeding and vomiting activity which falls outside of the expectation of the already "Othered" leather bar, but the patrons accepted this activity and supported the man, even though their own ideas of intimacy and trust had been challenged (Berlant and Warner 199, 206).

This story about a queer challenge to the heteronormative gave me a jumping off point for my study of the British filmmaker Peter Greenaway. Like queers and queer theorists, Greenaway "push[es] against the fixing of an indexical system," allowing more fluid ideas of gender, sexuality, race, and ethics (Stacey and Street 2). Greenaway breaks down binaries, boundaries, and 
expectations audiences hold with regard to characters and actions in films. Through feminist, queer, and postcolonial lenses, I consider the concept of the Other in Greenaway's feature films. Nearly all his feature films include a "nonstandard" Othering of characters whom one does not normally address as Others, a breaking down of societal binaries, and a challenge to societal taboos, as described by Prasad and Prasad in a chapter titled "Otherness at Large," where they describe the conflict between the "traditional Other" and the postmodern and global Other (57). This nonstandard Othering challenges the viewer to reevaluate his or her own subjectivity, and to evaluate which groups he or she fits into, as well as the value of these classificatory systems altogether. In creating fantastic worlds in which the characters defy the boundaries of the "real world," Greenaway's films deconstruct and restructure boundaries within the minds of his viewers, and thereby enact one of the tenets of queer theory. In finding our own images reflected in Greenaway's Others, we can begin to understand, encounter, and face external Others, as well as the Others lurking within our own psyches.

This thesis offers an original intervention. To date, much of the criticism surrounding Greenaway's films focuses more on the man than on his work. One exception is Amy Lawrence's The Films of Peter Greenaway. This book, however, was published in 1997, and over a third of his features have been produced since then. Moreover, Lawrence's book does not delve into the idea of the Other. While Douglas Keesey's The Films of Peter Greenaway: Sex, Death 
and Provocation, published in 2006, includes significantly more about Greenaway's features and offers useful insight, it too has little to say about the films' consideration of the Other as such.

Among Greenaway's specific works, The Cook, The Thief, His Wife, and Her Lover has received the most attention. ${ }^{1}$ Much of the scholarly writing about the film focuses on food, waste, and bodily functions. A notable exception is "Allegories of Thatcherism: The Films of Peter Greenaway," which explores the film's politics. But in all of these cases, as in published discussions of other specific films, little or nothing is said specifically about the treatment of Others and Otherness. By investigating a topic not extensively explored in the extant criticism, and by framing Greenaway's work within the theories described above, I go beyond the literature currently available.

Trained first as an artist, Greenaway has always pushed at the perimeter of society in both paintings and films. He himself says, "in a way, all my films are about outsiders" (Greenaway, quoted in Hacker and Price 192). These outsiders all represent the Other, but they manifest themselves differently in his films. As defined by Gabriele Schwab: "Otherness is created by deviations from culturally determined norms or transgressions of the boundaries that cultures draw in order to mark what they want to include or exclude (29)." Greenaway's films create many different "Others" His great and troubling originality is manifest particularly in cases where he inverts expectations, by Othering that which usually

\footnotetext{
${ }^{1}$ For a full plot summary see http://www.imdb.com/title/tt0097108/synopsis?ref_=ttpl_pl_syn .
} 
represents the self or the Same to his intended audience. He chooses to ask the viewer to reevaluate what is sameness and what is Otherness; as people find comfort in sameness (see Desmond 1), Greenaway makes his audience uncomfortable.

While some of the heterosexual characters in Greenaway's work fall comfortably into the category "heteronormative," many do not. Queerness in Greenaway's works can come from an identity the audience has never faced, such as that of the man in the leather bar described by Berlant and Warner. $\mathrm{He}$ outwardly presents himself as heteronormative, but his desires and actions place him in the subject position of the Other. Greenaway's viewers can see the kinds of "deviancy" to which queer theorists like Michael Warner, Lauren Berlant, Eve Kosofsky Sedgewick, and Judith Butler draw attention.

Also, instead of using the stereotypical "vulnerable women" as Others, Greenaway nearly always ultimately portrays men in a vulnerable position. For example, in his often criticized film $81 / 2$ Women, ${ }^{2}$ Greenaway portrays two flawed and fundamentally weak men, a father and son, who exploit women sexually. In the end, the women rise up and revolt, holding power over the men, and ultimately gaining their freedom. Repeatedly throughout his body of work, Greenaway takes great care to show men defeated by the flaw of "phallic pride," a pride, as Douglas Keesey indicates, that is perpetuated by the patriarchy but

\footnotetext{
2 Very brief (and somewhat incomplete, unfortunately) plot summary can be found here:

http://www.filmjournal.com/filmjournal/esearch/article_display.jsp?vnu_content_i $\mathrm{d}=1000697323$
} 
ultimately destructive for the men as well as damaging to the women (189).

The female Other in Greenaway films often breaks from the expectation of what she is "supposed" to be. In general, the women in his films have broken free from being Othered by society. They are not mere objects; on the contrary, according to Greenaway, "[n]o matter how humiliated or disenfranchised the women in my films are, they end up on top -- they're the victors" (quoted in Harris 73). The female protagonist is the character who changes and grows. The men "don't make any journey. They're virtually the same at the beginning as they are at the end," and this motif is common throughout his films (Greenaway, quoted in Harris 73). The director challenges the hierarchy of patriarchy and reevaluates women's power by disrupting the symbolic order in a Derridian way as described by Aalito and Mills. They dispute the notion that "[t]he symbolic order of gender that separates universes of the female and male sanctions a difference whereby what is affirmed by the one is denied by the Other" (24). This disruption of the patriarchy and reevaluation of sanctions, affirmations, and denials is a recurring theme. For instance, women in Greenaway do sometimes align somewhat stereotypically with nature, but instead of this alignment contributing to their hierarchic subordination to men, they use it to their advantage. Moreover, often Greenaway suggests that men should stop putting up boundaries between themselves and nature, and should rather use it to break down the boundary between what is "male" and what's "female." Douglas Keesey reminds us that Greenaway is almost always "less interested in preserving identificatory patterns 
and archetypal clarity than he is in challenging our habitual responses and stereotypical categories" (84).

Spatial displacement occurs repeatedly in Greenaway's narrative films. While in some of his films the Other is a traditional non-western foreigner (Kristeva, Powers 3), more frequently the European is the Other: geographically, culturally, socially displaced. Estrangements in Greenaway's films disrupt the representations of European control pointed out by Edward Said in his theory of Orientalism. To reiterate, we do not typically get the story of the foreign Other coming into British or American culture in Greenaway films; rather, the Other is European and thus audience members of European descent identify with him or her.

Finally, the monstrous Other appears in Greenaway's works (for one definition of the monstrous, see Art, Origins and Otherness 129). Once again, it is often the familiar, that which seems to represent the Same, that becomes the monstrous. If we think about Kristeva's interest in bodily functions and in horror, the taboo, revulsion, and fascination (see Creed 51), by the end of a Greenaway film, sometimes these things no longer seem as horrific as one might have thought at the outset. In addition, many times the films push the audience into the position of the monstrous Other. This Othering of the audience, suddenly faced with being monstrous, encourages a step back and a reevaluation of subjectivity. This subjectivity can be redrawn, as Kristeva suggests, after the notion of the Other has been collapsed. As she says, "'subject' and 'object' push each other 
away, confront each other, collapse, and start again -- inseparable, contaminated, condemned, at the boundary of what is assimilable, thinkable: abject" (Powers 18). Greenaway's films do exactly this: they break down the barrier between subject and other and make both reevaluate themselves, as new beginnings for both.

As viewers, we can make these journeys frequently in his films, and while such journeys are addressed in passing in the criticism, they are not really tied together. With sections on the displaced/foreign Other, the gendered and queer Other, and the monstrous Other, this study addresses Otherness across Greenaway's body of narrative feature film work. It synthesizes the existing scholarship and applies the ideas of the displaced, gendered, and queer Other to Greenaway's features, positioning the features within the critical discussion of post-colonial, feminist, and queer film theory. 


\section{CHAPTER 2: GENDERED OTHER}

As Amy Lawrence, author of The Films of Peter Greenaway states, “. . . the women in Greenaway's films must make their own way" (5). They do, often in spectacular ways. Greenaway's men, however, are weak or deeply flawed, allowing the audience quickly and easily to side with the women. Jonathan Hacker and David Price describe Greenaway's men as “[m]anipulated, helpless figures, [or] victims of fickle patronage," relinquishing control either to other men or, more notably, to women (192). As the power shifts to the women, the men become the Other. In his films, men are often controlled and manipulated by women who are looking for a way out of the corrupt, patriarchal and normative systems described by queer theory and feminism (see Berlant and Warner 347).

While many "mainstream" films perpetuate the gendered norms held by society, Greenaway strives to show us that nothing should be excluded from investigation by culture, and that many Others normally excluded by society are wrongly excluded. He shows that when things such as non-standard gender roles and "deviant" sexualities are excluded or marginalized, it causes great conflict in many of the members of the society. Greenaway looks at Othering within a culture, much as Foucault focuses on Otherness within a society. Through film, Greenaway interprets and critiques the societal norms described by 
Gabriele Schwab in The Mirror and the Killer-Queen: Otherness in Literary Language $(29,31)$.

\section{Women in Control}

Most often, women are in control in Greenaway's films, , taking them from the subordinate to the dominant and thus disrupting notions of Otherness, even if the men (and, at first, the audience) do not realize it. Women use their learned differences to manipulate men and escape the patriarchal system in which they have been reared. Sometimes the initial (often incorrect) reaction to female agency is that it makes the women seem as though they are the villains, but as with most things in Greenaway films, there are no distinct dichotomies or tidy answers, no clear heroes or villains.

In A Zed and Two Noughts, ${ }^{3}$ for example, the women initially seem mistreated by the men, but the women are much more involved in shaping the narrative than it seems, even when they are misguided in their desires. Disrupting the normal binaries Alba and Venus de Milo run the show; the men are at their mercy,. Allowing the men to think they are in charge, the two women try to pull the twins back from their grief after the death of their wives, as the men are ill-equipped to deal with it on their own. As Douglas Keesey, author of The Films of Peter Greenaway: Sex, Death and Provocation, asserts, "The women (particularly Alba) are stronger and have more self-knowledge than the men" (29,

\footnotetext{
${ }^{3}$ A plot summary appears here:

http://www.screenonline.org.uk/film/id/514723/synopsis.html
} 
30). The men are children who cannot function as civilized adults without a woman telling them what to do, which highlights and mocks stereotypes that are dangerous to the men as well as the women.

The man-child connection is also strong in Drowning by Numbers. ${ }^{4}$ The coroner, Madgett, regularly drinks warm milk and eats pudding out of a comically large bowl with a huge spoon, making him look like a child. The men in this film have always been so irrationally afraid of the female Other and of water that they have not been able function without something protecting them from the women and from water. Hardy eats a popsicle, and even penetrates his wife with it sexually, using it in place of his penis. This displacement keeps the men safe from the women, the Others they view as threatening. ${ }^{5}$

As Douglas Keesey points out, "All the males [even the child, Smut,] in Drowning are like children who try so hard to control things that they are bound to lose control" (68). Despite all their talk of control, these men cannot swim. They do not have the tools to negotiate the natural world as the women do. The men try to control nature, to build structures to control water without being in touch with it. Their phallic pride leads to their destruction. The message here is that anyone who tries to disconnect from nature will be destroyed, a message

${ }^{4}$ Incomplete plot summary here: http://www.britmovie.co.uk/films/Drowning-byNumbers Add to the end the hanging suicide of Smut for his guilt at suggesting his girlfriend jump rope in the road, where she is hit by a car because of his suggestion, and the drowning death of Madgett at the hands of the three women.

${ }^{5}$ In The Belly of an Architect, Kracklite suffers from the same childishness as the men in Drowning by Numbers. As he looks through the keyhole at his wife and Caspasian, he looks like a child peeking into his parents' room; the door dwarfs him and separates him from the action. 
repeated through many of Greenaway's films. This disruption of who has control of the world and who can effectively negotiate it Others the men and builds up the subjectivity of the women.

The Cissies in Drowning by Numbers, are one example of Greenaway's women fighting against being limited, defined, and Othered by patriarchy. Greenaway says the women in Drowning by Numbers represent "the three states of memorable misogynist antiquity ... the virgin, the matron, and the hag. But in this film, the virgin is no virgin, the matron is childless, and the hag is no witch. All are in charge. All are in control" (Steinmetz and Greenaway 71).

This theme of women's resistance and control follows through many of Greenaway's films, and the beginning of Drowning by Numbers even references them. The Skipping Girl, who jumps rope at the beginning of the film and counts the stars, mentions Spica, Kracklite, and Hoyten. These men from other Greenaway films have all fallen victim to their own systems of organization of the world, as men often do, as Jeff Hearn suggests in a chapter investigating men in organizations (Hearn 39). Phillip Holden-Moses, author of "Not Waving But Drowning By Numbers: Peter Greenaway's Cautionary Tale," says Greenaway’s men all destroy themselves through their phallic pride and childlike ignorance of the world around them. The knowledge they have does not equal the kind of power they desire. The women hold the power to understand the world and how it works (221). Greenaway's depiction of the men being less than the women and the women possessing the agency to negotiate situations in a meaningful way 
without the help of men supports the idea that Greenaway does not see women as an Othered subordinate to men.

Madgett seems as though he may be able to be rescued from the patriarchy, and he seems to try to help the women escape it as well (even pulling on their side in the tug-of-war), but his motivation is traditional heteronormative patriarchy, as becomes evident as he looks to dominate them sexually, physically, and emotionally. It is almost as if he realizes the danger of competing with nature, but he knows no other way, so he follows the rules of the patriarchy, even if they are self-destructive. In contrast, Prospero in Prospero's Books ${ }^{6}$ lays down his pen, allowing nature to be in control even though he has tried to control it for a long time. Through this action he, unlike Madgett and most other male protagonists in Greenaway, is able to survive the ending of his film.

In literary stereotypes, the "scary" female Other is defeated but, as Holden-Moss explains, the Cissies come out on top in Drowning by Numbers, defeating the patriarchy that has been holding them down and making them "sissies" (Holden-Moses 230). Greenaway reminds us that he used the fairy tale "Billy Goats Gruff" as his frame for this story. While the fairy tale upholds the patriarchy by having the biggest, strongest male goat win and take over, Greenaway turns it completely around, privileging "female solidarity over male individuality," thus freeing the women from being solely sex objects, as they understand their sexuality and what they want from it (Keesey 67). The men, on

${ }^{6}$ The basic plot of Prospero's Books is Shakespeare's Tempest, with the addition of his books, is described here: http://petergreenaway.org.uk/prospero.htm. 
the other hand, while powerful because of the patriarchy, cannot understand how to keep their egos in check. They get out of control for fear of losing their sense of self. Douglas Keesey builds on Greenaway's own words and suggests that in going it alone, the men isolate themselves, whereas the women can use their relationships with each other and with nature to gain strength (77). The Cissies bend the rules, but since the rules were set up for them to fail, it is the only way they can break free of the unfair structure set up against them. The Cissies in Drowning by Numbers, like many of the other women in Greenaway's films, direct the action through their manipulation of weak, child-like men who try to regulate and classify nature. The Cissies' sisterly relationship and solidarity threaten and eventually destroy the men around them, who are too arrogant to ask for help and have to have a hierarchy, a rank, and a winner in order to feel as though they are significant.

The control of women over men is also present in Nightwatching. ${ }^{7}$ Rembrandt's wife, Saskia, orchestrates all the action. She runs the house almost as an emotionless monarch, even to the point of instructing Rembrandt on the finer points in telling him to close the shades when she is very ill. She sits in a throne-like chair while he sits below her on the floor, even putting his head on her lap and weeping. Here he is emotionally beneath her - a subordinate - as is shown by the actions as well as in the shot's composition as he sits on the floor at her feet. Strong and with a plan, Saskia sits matter-of-factly while Rembrandt

${ }^{7}$ Plot summary available here: http://petergreenaway.org.uk/nightwatching.htm 
breaks down and denies the reality of the situation. She knows that she is going to die, and he refuses to believe or accept it. This role-reversal Others Rembrandt and positions him in an unconventional role for a man: he is positioned physically below her in the scene, a weeping, desperate figure while his wife is strong and silent.

In The Draughtsman's Contract, ${ }^{8}$ Neville, the Draughtsman, finds himself in the middle of a murder plot possibly directed by dispassionate women. Greenaway does not give the audience the satisfaction of a clear ending, so the question of who actually committed the murder of the patriarch of the household is never answered. Douglas Keesey says Neville's arrogance and attempt to regulate nature through his meticulous orders regarding sketching the grounds result in his destruction (64). This attitude is reminiscent of many of Greenaway's other characters. He thinks he is directing nature, and he is in control of the situation. He thinks he knows everything going on in the whole narrative, only to find at the end that the two women have drawn him in and have not only framed him for a murder, but conspired to have him father a child to be the heir to the land. He has become thesubordinate Other, having his story written by women who thus disruptthe typical Othering. Queer theorists Stacey and Street suggest that women, normally the subordinate, can bring themselves to the top and thus "win." They are not subjugated by men (32). The women have agency, and the audience wants to see them be successful.

${ }^{8}$ Plot available here: http://www.screenonline.org.uk/film/id/493658/synopsis.html 
The murdered husband is portrayed as brutish and corpulent. His appearance at the beginning of the film does not encourage a sense of loss in the audience when he is later found dead in the moat. The infertile (or possibly impotent) husband of Mrs. Talmann is portrayed as someone who disregards women and their wants and needs. His desire for land and power overshadows any care he has for the women in the house. The men in the film take little action except to prance and preen with their elaborate clothing and discuss how best to gain power over the land, the household, each other, and the women.

As in many of Greenaway's films, the female protagonist Nagiko in The Pillow Book is initially Othered and marginalized by her arranged marriage, a heteronormative patriarchal marriage. Later she escapes this marriage and ultimately seeks out female language much as Kristeva describes it, which allows her to defy the patriarchy and the world external to herself that is trying to define her (Schwab 27). Her threatened husband is too entrenched in the patriarchy to accept anything outside of the "normal" and rejects her needs. This rigid patriarchy causes her to try to break free from it. However, in seeking out men to write on her body, she initially perpetuates the patriarchy herself, just in a different way. The men are still writing her story, and her becoming a fashion model is not a step in the right direction. From a Lacanian standpoint as described by Schwab, her actions do nothing to address her internal wounds, and her relationship to language is not helping her heal them (27). Still an object

\footnotetext{
${ }^{9} \mathrm{~A}$ very good plot summary appears at wikipedia and is correct as of 11 Feb 2014. http://en.wikipedia.org/wiki/The_Pillow_Book_(film)
} 
rather than a subject, she tries to protect herself from the male gaze by creating a persona and hiding behind it, but eventually this fails, and her subjectivity becomes intertwined with her outward appearance as a model.

Men are afraid of her, almost child-like in their hesitancy to write on her body. They will have sex with her, penetrate her physically, but they will not share what for her is true intimacy through writing on the body; they are too frightened, and they do not care enough to join her emotionally. Jerome, however, abandons the patriarchy and becomes the Other. He asks Nagiko to write on him, thus becoming the man allowing the woman to write his story. Resistant in the beginning, she thinks he should write on her because that is what gives her pleasure. She has been conditioned to allow men to write her story. However, this moment becomes an epiphany that allows Nagiko, now in the dominant position, to break out of the patriarchy and begin to have agency of her own. This is an instance of the notion that, as Aalito and Mills suggest, the terms "man" and "woman" can become more fluid, rather than being structured binaries that cannot be broken, and this fluidity "undoes" the notion of Otherness (36).

Jerome helps support Nagiko in her new role as writer as she writes on his body, but he also writes on hers. Their relationship is much closer than others in the film to that of true equals. They each complement the other, which adds to both of their lives, and takes nothing away from either. During the sex scenes, they are both shown as dominant at times and at others as submissive. The ideas of "masculine" and "feminine" are gone from their relationship., Though 
many within the patriarchal world view would see Jerome as passive and thus feminine, the audience is reassured that difference does not mean a value judgment must be made. The characters move back and forth, being different subjects at different times, a balance queer theorists like Berlant and Warner advocate (344).

Jerome seems exceptional, for in the world of Greenaway's films, men are nearly always subject to phallic pride and dominating others, and these nearly always equal death.

In $81 / 2$ Women, while the first section of the film outlines the desires of the two men, Phillip and Storey, the women ultimately take all their money and escape the patriarchal system and gain agency (a familiar Greenaway theme), leaving Phillip dead and Storey emasculated. At first, for money, the women do as the men please, but upon realizing their objectification, they break down the power structure for their own benefit, turning the men into Others in their own home. While in its namesake, Fellini's $81 / 2$, when the women try to take over they are dominated by Guido and his whip, the women in Greenaway's film successfully remove the men from power.

Though the men in Greenaway's films are continually manipulated by the women, they continue to try to force women into idealized constructions, but their pride and their attempt to control the female world ultimately lead to destruction. Keesey suggests that in depicting men's attempt to fetishize the female ideal, to create a simulacrum on canvas (or on film, or in culture at large),, Greenaway's 
films warn men that this activity will destroy either themselves or the women around them (32).

\section{Male Marginalization}

While women are most commonly marginalized in film and literature, Greenaway challenges this notion by marginalizing men as well, even though not all the men are marginalized, and not all the men seek to marginalize others. Greenaway also asserts that women who seek to marginalize can fall into the negative side of the dichotomy perpetuated by the patriarchy, and the ideas of a gendered hierarchy can cause women's destruction as easily as men's.

In Drowning by Numbers, Madgett focuses on games, and after the death of Jake near the beginning of the film, the game being played is "Dead Man's Catch." The four remaining men, Hardy, Bellamy, Smut, and Madgett, are all eliminated from the game in that order, leaving only the Cissies playing it without error. Douglas Keesey suggests that the men cannot follow their own rules and, in turn, lose control of the phallus, represented here by juggling clubs (15). The women easily negotiate the space, whereas the men fail at their own game, foreshadowing the death of the men, as they are all eliminated from the game in the same order in which they later die in the movie. Through the men's inability to play the game and the women's understanding and negotiating both the game and the patriarchy for their own benefit, the audience sees how the women will ultimately be victorious. 
Alternate, and even "taboo" sexuality appears in Drowning by Numbers to show how men are victimized by the patriarchal norms expected of them. If they try to exist outside of those norms, they risk being destroyed by expectations just as women are victimized by the patriarchy. Madgett, while walking with Cissie \#3, confesses his necrophilia to her. Far from being horrified or shocked, she continues to ask questions. While Madgett has been presented up to this point as someone deep within the patriarchal norms, this conversation exposes his own misunderstanding of how to negotiate the patriarchy. He tries to dominate women, manipulate them, and marginalize them. He, however, has not been able to convince a woman to be with him through the methods the patriarchy has taught him. He has been forced into violating an absolute taboo in order to try to connect with women. Through the conversation he exposes his fear of rejection, as he says "Corpses. . .won't reject you” (Drowning.) He realizes that he has been rejected by all three of the Cissies. When he feels he has control of them through their blackmail he is a perpetuator of patriarchy; when he feels himself a failure through his inability to obtain a woman, he is a victim of the same system, and because he cannot change and adapt, the women kill him.

Smut attempts to take control of the feared Other, in this case death, in order to neutralize it. Smut's attempts to count and categorize "violent deaths" through his painting system ultimately lead to the death of the Skipping Girl and in turn his own death. She counts the stars at the beginning of the film, but accepts that there are more than she can possibly count; Smut, on the other 
hand, counts to take control. He is so confident in his system he tells her she can go into the road because of the day of the week on which she is jumping because it is the safest day according to his categorization. He tells her she will have more room to jump rope and will better be able to see the stars she is counting; this better view is unimportant to her, but with his ideas of control, he thinks she needs to see everything for her action to be meaningful. She trusts his very logical system and is hit by a car and killed. Smut, realizing that his own phallic pride has destroyed her, hangs himself in the tree with her jump rope. Since he is still a child, and has not been completely interpellated into the ideology of the patriarchy, he is still learning from the patriarchy how to be a man. Because he is not yet a man within the patriarchy, he realizes that there are no winners within the patriarchy, and that "the winner is also the loser" -- both men and women will suffer within it (Drowning). The men fully invested in the patriarchy have a difficult, if not impossible, time recognizing the things Smut realizes.

Male rivalry for control over the Other is evident in The Cook, The Thief, His Wife, and Her Lover. Spica fears being toppled as "King of the Mountain" (to invoke a Madgett-like children's game) and marginalized, so he tries to assert his masculinity over others because, Georgina tells us, he is homosexual. The "evil gay" is a trope unfortunately perpetuated even today within mainstream film, but Spica's aggression comes not from the fact that he is homosexual, but that he is afraid to accept his homosexuality. He compensates for it by being hypermasculine. He abuses Georgina sexually, but does not have heterosexual 
intercourse with her. He marginalizes her by enforcing what Adrienne Rich has called "compulsory heterosexuality" (Ryan 131-132).

He disparages the genitals of nearly every other male in the film in an attempt to regulate his own desire for their penises. Mitchel, one of his gang, is directed to pretend to eat prairie oysters, and then at the murder of Michael, Spica tells Mitchel to remove Michael's testicles with his teeth. Ultimately, Georgina instructs Spica to eat Michael's penis, with the sexually charged comment, "Try the cock, Albert. It's a delicacy, and you know where it's been" (Cook). His knife and fork hover briefly over it, but he moves away from the penis, and Georgina kills him shortly thereafter. This reference to the literal consumption of the male flips the marginalization of women, as they are very often the ones described as edible or as property, as Amy Lawrence describes (186).

Sex for Nagiko's father in The Pillow Book is a commodity; he is himself an object of exchange. Through becoming a sexual object of exchange, he becomes the marginalized Other. The use of sex as a commodity is almost exclusively depicted in terms of a woman selling her body, but in this case it is the father selling his body in exchange for the publication of his word. This commodification and dehumanization of her father leads Nagiko to seek revenge on the publisher. As her revenge fantasy against the publisher in defense of her father's place in the patriarchy continues, she begins to emasculate Jerome. She dominates and writes on him, and also sends him to the publisher in order to 
have her works published, reproducing exactly what had happened to her father that she found so vile and dehumanizing. Keesey suggests that Jerome embraces his more fluid sexuality and has sex with the publisher to help Nagiko, but reflecting the earlier trauma of her father, she loses control of herself and falls back into the role of the marginalized (171).

Her revenge for her father against the publisher does not reach fruition at this time. Instead, after the death of Jerome, she takes control over her own life, and in doing so she is able to exploit the phallic pride and greed of the publisher to destroy him in a later plot. She was not able to do so before because she was so blinded by anger. Nagiko and Jerome's story, written on Jerome's corpse, is in the possession of the publisher, as he has stolen the skin off the corpse to keep the beauty of Jerome (and Nagiko's writing) with him forever. Nagiko gains control over the publisher, sending stories written on the bodies of various men. He becomes more and more dependent on the art for his livelihood, eschewing other methods of income. Through this control over him, she writes their stories, the publisher's story, and her own. She is no longer marginalized or dependent on anyone. Completely dependent on Nagiko, the publisher follows down the path to his own destruction. Keesey suggests that she could not have destroyed him if he had not been so blinded by his own phallic pride, narcissism, and blind allegiance to the patriarchy (180).

In The Baby of Mâcon, the Daughter controls much of the action, taking up the mantle of the patriarchy. Her figurative "phallic pride," in the form of her intact 
hymen, the source of all her power, is her ultimate downfall. Much like the pride men take in their phallic power, her pride and power are her intact hymen, her "proof" of her (bogus) status as a virgin mother. She becomes so much like a man focused on the power his genitals bestow on him that she is susceptible to the same fate as a man who falls through his phallic pride. In locking away the Mother, the Daughter fills the role of the male, locking away the maternal. This behavior ultimately contributes to the Daughter's destruction. Greenaway seeks to remind us that a direct inversion of the binaries can simply lead the now powerful woman down the same path that men have traditionally followed. Unchecked power corrupts in this film, and the Daughter, instead of using her power productively, uses it in a negative way. Greenaway suggests that it is good for women to gain power, as long as they do not fall into the same traps as men.

\section{Reproductive Other}

Pregnancy and reproduction are near constant topics in Greenaway's films, from the pregnant Cissie \#3 in Drowning by Numbers to Georgina in The Cook, the Thief, His Wife, and Her Lover. The reactions of the men around them, as well as the way in which women deal with their own fecundity and the power it brings, or the power lost through it, are topics not normally addressed in cinema. By giving these topics time on the screen, Greenaway helps undo some of the notions an audience may have of this rarely represented Other. 
In The Belly of an Architect, ${ }^{10}$ Kracklite and Caspasian treat Louisa differently with regard to her pregnancy. Caspasian notices that she is pregnant, while Kracklite does not. Whether honestly or not, Caspasian (who is not the baby's father) tells Louisa that he finds pregnant women beautiful, though he may just be using her pregnancy as the "perfect contraception" (Belly). (Compare Georgina in The Cook, The Thief, His Wife, and Her Lover, who mentions the fact that her infertility makes her safe from pregnancy). Greenaway himself has noted that in general through western history, the pregnant female form is not one that is often addressed outside of the "divinely pregnant" Mary. Though fertility certainly comes through as a topic of discussion, the pregnant female form is excluded as an Other. His opinion is voiced in Architect by Flavia, who says "of all the female statues in Rome, not one of them is pregnant" (Greenaway in Melia and Woods 111).

Amy Lawrence suggests the effect of the simultaneous occurrence of Louisa's pregnancy and the opening of the exhibition Kracklite is in Rome to design. Greenaway's film shows that Louisa has the ability to accept the separation from her child through birth, while Kracklite does not have such an ability with regard to the exhibition; he wishes to continue to control the ideas once they are outside his head, and he cannot accept anyone else's influence (160). While Kracklite's response to the birth of the exhibition he lost control of is to kill himself, Louisa accepts the loss of control of her child through his birth.

\footnotetext{
${ }^{10}$ A plot summary can be found here:

http://litmed.med.nyu.edu/Annotation?action=view\&annid=10111
} 
Kracklite's own death was impending in any case, but his suicide at the exhibition makes the point that he cannot handle the loss of control either of his own body or of the exhibition. Kracklite and Louisa are moving in opposite directions with regard to the independence of their creations. The female Other here is stronger than the dominant male in the knowledge of appropriate control.

In Nightwatching, Rembrandt says that his painting will take 9 months to complete, mirroring the pregnancy his wife has just gone through. While (with input from Saskia) Rembrandt rules the space on his canvas, the women rule the birthing space, excluding him from the space as Saskia gives birth. The women surround the bed and force him to leave, seemingly to reaffirm that birth is women's realm and he has no right to be there; he is Othered by his maleness in this space. In contrast, when death is the subject, surrounding the bed are mainly men. The film tells the audience that women are dominant in reproduction, whereas the men are primarily responsible for death. Similarly, Smut's main focus in Drowning by Numbers is death, the opposite of reproduction. He presumably inherits this obsession from his father, Madgett, the town coroner. Madgett molds Smut, whose mother is absent without explanation, in his own image: obsessed with death.

While pregnant women are shown in nearly all of Greenaway's films, women's ability to reproduce is sometimes challenged. But when the men try to reproduce themselves without a woman around to do the actual reproduction, they always fail. The metaphor of men and women reproducing together plays 
out in nearly every film, even if the men are merely "sperm donors" or the women merely incubators. The twins in A Zed and Two Noughts are copies of each other, but they need Alba to reproduce themselves in the next generation. In The Belly of an Architect, Kracklite photocopies images of torsos in an attempt to take control of his own life, but he needs Louisa to produce an heir. In The Draghtsman's Contract, Neville copies down what he sees in front of him, even to his own detriment. But the women use him to reproduce successfully and thus ensure their future control of the estate. Rembrandt struggles to create without Saskia to guide him. All of the examples remind the male that he is not in control. $\mathrm{He}$ is the gendered Other with respect to reproduction. This undoes the idea that reproduction and nurturing are in service to men and that women are thus subordinate to men because of their ability to reproduce. Indeed, women lifted up as strong mothers who can participate in society beyond simply being mothers break the traditional binary hierarchy of men and women, in which the woman is always the marginalized Other (see Aalito and Mills 58, Schwab 36).

Intersex people and animals are other reproductive topics in many of Greenaway's films, as they too break the male/female binary. Queer theory challenges this binary (Stacey and Street 13). In The Belly of an Architect, Louisa tells Caspasian she thinks his sister Flavia is intersex, though she just seems to the audience to be a powerful and independent woman. Louisa may not be able to accept that a woman can be strong and independent without a penis of her own. Louisa has men take her places and tell her what to do, whereas Flavia 
asserts her own opinions and her own thoughts. Louisa's attitude shows how the patriarchy affects the way that women think not only about men, but about other women, and ultimately about themselves. While the film initially seems to perpetuate the binary of strong men and weak women, Flavia, who is not intersex, as Kracklite discovers, nonetheless breaks the binary of strength and weakness. By the end of the film, Louisa herself has become strong and independent, in part because of her relationship with Flavia. The men at the end of the film are nearly all weak or dead, whereas the women have been built up and are strong.

Snails are addressed more than once in A Zed and Two Noughts, and also appear at the beginning of Drowning by Numbers. They are intersex, and according to Oliver, they can "satisfy their own sexual needs," eliminating the need for the opposite sex. At the beginning of Drowning by Numbers, HoldenMoses tells us the snails are a clue that the men are not good partners for the women, though the women need them for a short time to reproduce, as Cissie \#3 shows (229). This assertion (like the behavior of the women in The Draughtsman's Contract) balances out the men's desire to reproduce on their own. The partners balance each other. There cannot be one over the other in a society.

The Belly of an Architect sets up the gendered Other right away as architect Kracklite and his wife, Louisa, conceive their child as they travel into Italy on a train. As the train crosses the boundary into Italy, which will ultimately 
be the scene of the birth of the child and the death of the father, shots of the spouses are interrupted by graveyards and buildings that are nearly ruins. As Douglas Keesey says of this scene, "This crossing of man into his 'other,' woman, inseminates new life, the son who will succeed but also replace Kracklite the father, the impregnation marking Kracklite's movement in time, into birth and death" (46).

Greenaway says that most of the men "don't make any journey. They're virtually the same at the beginning as they are at the end," once again a common theme throughout Greenaway's films (Greenaway in Harris 72). The men who seem to be the protagonists are really just static characters. Through this undoing of our expectations, Greenaway tells men that they must change in order to grow and be better members of society. They must not uphold the patriarchy. He challenges the hierarchy of the patriarchy and reevaluates women's power and represents them as having subjectivity and agency rather than having them always be the Other.

Greenaway often shows us the culturally created differences between men and women, frequently through erotic expectations. He seems to believe, with Levinas, that people can use the learned differences to help eliminate them (Hand 8-9). Greenaway also, like Berlant and Warner, wishes to uphold the idea that sexuality has no norms - and no Other -and he seems to strive to include myriad sexualities to help the audience reconsider what they consider normal 
and perverse, and whether these terms can even apply (Berlant and Warner 345). 


\section{CHAPTER 3: THE DISPLACED OTHER}

In addition to the gendered Other, another of the large themes Greenaway tackles in his films is the displaced Other. Whether portraying a more traditional "foreign" Other, or a person attempting to navigate a society, culture, or class not his or her own, Greenaway once again challenges the audience to face alternative subjectivities.

\section{Geographically Displaced}

Jerome in The Pillow Book is a displaced Other-- a Westerner in the East. Many of the kinds of things the audience commonly associates with Easterners in the West they now hear about Jerome. Nagiko complains his appearance is foreign. She dislikes the look of his penis in comparison to the men she normally sees. Applying an Asian norm, she finds him to be excessively hairy--so hairy that in her eyes he is only half naked at any time. She rejects men from other races, repulsed by their bodies, but these reactions come not from actual experience, but from preconceived notions of how the Other must be.

She also Others him through his use of "ugly" western letters. Struggling through the time he paid for with her, disgusted by everything about him, she shows us just how foreign someone so "normal" to the western audience can be 
in a displaced situation. Ultimately, however, we see how changed she is by the encounter with the Other, and how it changes her subjectivity in a positive direction, in keeping with theories on encountering Others by Gisela BrinkerGabler (3). This reversal of the Other shows the audience how generally absurd people's observations of foreign Others can be. The view of Jerome through the camera certainly softens as Nagiko's emotions change toward him. At first, we see what she sees; we see his hairiness, the awkwardness in his writing. As the film continues, however, the lighting changes, the camera moves in closer and views him more as a person, and Jerome is shown as an attractive partner for Nagiko both physically and emotionally. The key shot for her (and the audience's) acceptance of him shows him in bed, soft lighting coming from behind, covered in her writing.

Greenaway also exposes the English-speaking audience to a foreign language as an Other in The Pillow Book, in keeping with Gabriele BrinklerGabler's ideas about how establishing new meanings can affect an audience (3). Because they are not given translations of certain things, the audience feel as though they are the Other. Without translations, there is a gap in the audience's knowledge of what is happening on the screen. Most people will reject what is untranslated as unimportant, but in struggling to find the familiar within the unfamiliar, the audience is asked to accept the alien Other, and understand that everyone can be in that Other position. Ethnocentrism is challenged through this Othering of the audience (Brinkler-Gabler 5). 
Nagiko's encounter with the animal Other reminds the audience of these ideas as well. The story of the color-blind whales and their differing experiences in the world, shows that many creatures, just as people who are foreign to one another, have different experiences and categorize and view the world in different ways. In simply translating, one displaces and dominates the Other, who is in effect destroyed by the effort of translating. As Mary Ann Doane says of translating: the desires of the translator are projected onto the translation (179). Greenaway himself has commented on his omission of subtitles: he says, "our overall literary education ... persuades us to trust text more than images" and suggests that when words appear on the screen, we will pay attention to those, not the images, thus subordinating the images to the words (Greenaway quoted in Woods 273). To avoid privileging one over the other in The Pillow Book, he says, he does not sub-title much, allowing the images and sounds to work together, even understanding that people will not understand the words. This action tries to eliminate some of the "unfamiliarity with the sounds of foreign languages." This unfamiliarity can lead, in Greenaway's words, to "ignorance" and even "xenophobia" (Greenaway quoted in Woods 273).

Greenaway uses The Pillow Book to help fight notions of foreign Others as "freakish" (Greenaway quoted in Woods 273). His view fits with the theories of Edward Said in Orientalism when the latter address the resistance to foreign languages as a source of propaganda (293). Knowing and accepting the Other means understanding that meaning varies between cultures. Thus in one 
example of linguistic differences in the film, a calligrapher tells Nagiko that the Korean symbol for "heaven" is the same as the Japanese symbol for "sage brush smoke" and to know each other, we must accept differences (Pillow Book).

Nagiko struggles to find her place within the male/female structure, but also within the Chinese/Japanese opposition. She does not know how to identify herself, a common theme in both feminism and queer theory (Hall 93). Like Gloria Anzaldúa, ${ }^{11}$ Nagiko experiences a split subjectivity affecting every part of her being. She is unable to function completely within either society. She escapes her Japanese subjectivity, which dominated her in the arranged marriage, only to find a different set of subject and agency problems in Hong Kong, which is itself split between Eastern and Western values. Greenaway repeatedly tackles the question of finding one's place in the world, and the only answer he gives is that everyone has to find his or her own place, regardless of, or in opposition to, the subject position forced upon him or her. He shows both Nagiko and Jerome gaining agency and fulfilling their desires in their attempts to find their place within a foreign world. Jerome has Othered himself, in many ways, by choice. He chose to leave his native Britain to live in the East. But there is no place for Nagiko to go to find cultural comfort, so she must create her own space in which to grow and flourish. She does this at the end of the film. Her location is unknown, but her happiness shines through.

While in Greenaway's work one dimension of the writing of people's stories involves resistance to the patriarchy writing the story of women as

${ }^{11}$ See Gloria Anzaldúa, Borderlands. 
described in Chapter 2, another dimension involves resistance to the colonizers writing the story of the colonized. Here Edward Said's concept of Orientalism comes into play. ${ }^{12}$ Together, Nagiko and Jerome investigate the Eastern "written character." The double meaning of the word "character" drives the idea of the colonial rewriting of histories: the characters of the language have not been allowed to write their own stories. The film speaks out directly against the colonial rewriting of Asian identity described by Said (3). Jerome, in refusing to write on Nagiko and allowing her to write on him, symbolically breaks the colonial grip of the West on the East. Instead of the West writing the story for the people of the East, Jerome and Nagiko can together write a shared story. In a 1997 interview Greenaway discusses how The Pillow Book accepts the validity of writing lists in the way of the East rather than in the Linnaean system used in the West (Greenaway in Hawthorne 7). This sort of inclusion of differing systems of organization throws the audience out of balance and may encourage a reevaluation of subjectivity and logic. One cannot assume that his or her own way of thinking about the world is the only one, or that it should be privileged over another.

$81 / 2$ Women presents another example of European men traveling to the East and becoming Othered. The father and son have no idea how to assimilate to the culture in Japan, even though they own pachinko parlors. They are using the parlors as they do everything else in the film: for their own personal gain, and to feel superior to the Japanese. They make no attempt to understand the

${ }^{12}$ See Edward Said, Orientalism 
importance of the game to the Japanese, nor do they care to. For them, the parlors are a source of power and money. As Lawrence explains, the men are the epitome of colonialism and of the West's forcing definitions of subjectivity upon the people of the East, just as they also represent the use of money and power to try to rein in the women (136). The hope of this film is that the definition of subjectivity that the West has placed on the East can be escaped just as the women at the end of the film escape the patriarchal subjectivity that has been imposed upon them.

Another of Greenaway's most striking examples of a displaced other is in The Belly of an Architect. Stourley Kracklite is an architect who manages to "Other" himself from his own culture and history in every way he possibly can. As described by Lawrence, he is an American architect, not very well known, who travels to Italy to set up an exhibition in honor of an even less well-known French architect from the 18th century named Étienne-Louis Boullée, known for his use of spheres (Lawrence 136). Clearly a foreigner in Rome, Kracklite struggles to find his way to mount the exhibition, and in fighting with his exhibition team in Rome, he butts heads with the Italians. One of them, Caspetti, insults Kracklite's choice of architect for the exhibit and questions whether or not the exhibit will appeal to the people of Rome. Another, Caspasian Speckler, steals money to do a restoration of Mussolini's sports forum. Because of these actions, Kracklite begins to feel that all of these people have been against the exhibit, against him, and against Boullée from the very start. So ostracized, Kracklite loses all of the 
things important to him over the course of the film: his exhibition, his wife, and finally his life. He is completely dependent on other people, but unable to cope with the loss of independence within another culture. As Lawrence points out, his arrogance does not allow him to see that he is losing control of every aspect of his life: work, marriage, and ultimately his health (he is diagnosed with stomach cancer) (Lawrence 115).

Greenaway once again does not invite the audience to align with a specific character or a specific group of people. From the cultural perspective of Greenaway's British and American audiences, Keesey explains that, though the Italians seem to be doing awful things to Kracklite by trying to take over his exhibition and even his wife, the editing of the film, through shot/reverse-shot, lets the audience see the frustration of the Italians, marginalized through much of the history of the twentieth century. This episode is for them an opportunity to exact revenge on the American ego and return some focus of attention onto themselves (49). While the film is not set in Asia, the concepts of forced subjectivity can be seen through the subject positions of the Italians. They feel as though they need to fight against the subjectivity imposed upon them during the second half of the twentieth century by the countries that made up the Allies during World War II, with the Americans (represented by Kracklite) being the "worst" culprit in terms of enforcing a definition of what the Italians should be.

The film is critical of the American mindset. Keesey notes that Kracklite takes credit for none of the hardships that befall him (49). He is completely 
narcissistic, viewing only his own wants, desires, and needs as relevant. The continuation of life relies on some sort of contact outside of the self, but he is so focused only on himself that his narcissism serves to destroy him. He responds to criticism through violence and yelling, only setting himself culturally further away from the Italians he is supposed to be working with. All of these factors, along with his impending death from cancer, lead to his suicide at the end of the film.

In Greenaway's Prospero's Books, Caliban is monstrous and displaced, echoing the character's portrayal in Shakespeare's Tempest. Caliban is born of a witch, misshapen, and very animalistic in his form, fitting many of the stereotypical "freak show" descriptions as explained by Nadja Durbach (135). Prospero partially educates Caliban alongside Miranda, but echoing the colonial treatment of the children of "foreign" servants and slaves, Prospero declares him unfit for more education and certainly unfit to marry his daughter. Caliban is the savage, prohibited from entering the realm of his enslaver as an equal.

Prospero's definition of Caliban is the subjectivity he projects onto Caliban, not the subjectivity Caliban would write for himself as he struggles with Prospero's version and tries to escape it. Prospero invents Caliban's identity, just as Said explains the west does to the East (1). Caliban's graceful dance movements reveal that though he looks animalistic with his bright red testicles and his hunched and painted body, he has a oneness with movement that no other character has, and his ballet shows the beauty within the character 
described as monstrous. Nonetheless he has been tracked as evil and has embodied that identity, much as Edward Said argues, in Orientalism, that the identity that the invading body forces onto the native body becomes true through its repeated "truth," even though it is not true at all (1).

Caliban wishes to break free from his enslaved identity. The only way he knows how to do so is through the murder of Prospero to remove him from power. Prospero's books must be destroyed with him, for the books hold the knowledge and power. When the audience sees Caliban defile books, the automatic response is to be shocked and horrified by their destruction, but the "education" Prospero has provided Caliban is what has defined him as a devil. These books have taken him from a well-integrated identity to a state of unnatural subjectivity defining, restricting, and punishing him.

Similarly, language itself, as so often in the colonial power structure, is used to marginalize the colonized. Prospero refuses to acknowledge any value in Caliban's native language. This language is primarily dance and movement, beautiful in form. Amy Lawrence explains that Prospero is scripting the words that come out of the mouths of the characters, but Caliban can escape his forced definition through dancing; he can thus move outside speech, which is controlled by Prospero (142). He tries to break free from the bonds Prospero holds on him. As Douglas Keesey says, "Caliban's physical contortions might be a reaction to that demeaning role, an attempt to wriggle out of the verbal construct in which Prospero has confined him" (107). 
Near the end of the film, Greenaway presents a turn for Caliban that is brief, but significant in scope. Caliban has been the destroyer of books through the film, but at the end, when Prospero throws Shakespeare's first folio (minus The Tempest) and his own penned Tempest into the water, it is Caliban who swims to save them. The savage saves some of the most important texts in western literature. Through this action he can begin to write his own story because he breaks free from the expectations put onto him by Prospero. Until this point, he sees the books as bad because Prospero uses them against him. Earlier in the film he threw feces, vomit, blood, and urine onto them. In picking up the books now, he recognizes that they are repositories of knowledge. Through this action he breaks the identity created for him by Prospero, so that he can replace it.

A foreign Other who appears in Prospero's Books is the King of Tunis. This Other embodies stereotypes, but once again we are reminded that these images are not universal truths, but they are the "truth" as filtered through a western, Renaissance lens. The image presented of the King of Tunis is that of a large dark-skinned man, when the reality is that the people of Tunis, while African, are very light-skinned, looking much more like Europeans than the "scary" Africans. This image is used to frighten Europeans about the nature of the Tunisian Other. Greenaway wants to remind us that this latter is a construct, not reality. He does this through the absolute absurdity of the image and the clichés presented in it. When we first see him, the dark King of Tunis, wearing a 
loincloth, is being wiped down by attendants. He has a stern look on his face and he stares into the distance coldly. Claribel lies in the foreground of the image, her genitals and thighs covered in blood, and she is weeping. Many audience members are shocked by this racist image and indict Greenaway for using it, but when Prospero is shown in a nearby mirror, one has to accept that this is his idea of reality, not the actual situation. It is as flawed as the rest of his images, as are many of our images. This flawed lens on the other, incorrectly represented as a mirror, continues to establish Prospero and the rest of "western society" as an unreliable narrator.

Normally, natives of a colonized place are defined as savage, as Caliban is here by Prospero, but Greenaway shows us that this definition is indeed incorrect. The natives of the island, as a whole, are often nude. Through Greenaway's lens, we see their innocence and uncorrupted nature. They are sometimes sexual in their movement, but that movement is beautiful. It shows that they are not covered and corrupted by European Renaissance society. In contrast to unashamed nudity, the ridiculous clothing of the noblemen looks even more absurd than it might on its own, clearly defining them as Others, outsiders, on the island. They are hindered by their clothing. Only their heads, and sometimes their hands, are visible. Greenaway describes how their neck ruffs create nearly disembodied heads, so detached from their bodies that they may not even realize that they have bodies, for they cannot see them ( $A$ Film of Shakespeare's The Tempest 100). They are highly artificial in their attire, and 
look very uncomfortable thrust into a world of water and nature--so much so that they cannot follow Caliban into his pool. They echo the men in Drowning by Numbers in their use of protection against nature and water, and possibly in a lack of ability to swim well. They use absurd clothing to protect themselves psychologically from anything natural.

The framing of the nude bodies of the natives during the wedding scene takes many people aback, as breasts and penises are unashamedly displayed, framed front and center, one at a time, just behind the procession of gifts. This framing deliberately Others the audience, as we live in a culture that has come out of the Renaissance (and Victorian) sensibility of the body and clothing. This display challenges the prudishness of the audience. Throughout his body of work Greenaway challenges the idea that nudity is always sexual. Clearly, these figures are not aroused; they are not engaged in any sexual activity. They are simply nude. Greenaway's use of nude bodies of all shapes, sizes, and ages also challenges the notions of beauty in the western world. Traditionally, the Other is a person who does not fit into the standards set up by society. In the worlds Greenaway creates, it does not matter what someone looks like.

Prospero himself is a displaced Other within the context of both the natives and the noblemen. He has been expelled from one land, and he has taken over another. He is a part of neither of them. He writes the story to destroy his rivals, but in the end is called back to be a part of their world. Moving from his elaborate decorative island clothing, by the end of the film he is back in his 
nobleman's clothing to rejoin the European world. He has been changed by his experience on the island, but he has a strong desire to return to the world he views as "normal" even though it has rejected him, a desire discussed by Mary Ann Doane in regard to racial others, but that can apply here to Prospero (218).

\section{Displaced at "Home"}

Greenaway wants to show it is possible to be the displaced Other when in one's home or homeland as well. For example, the twins are a displaced Other in A Zed and Two Noughts. We do not typically think of twins as a foreign Other, but we see the twins come together so that they are as conjoined as they were when they were born. Durbach reminds us that conjoined twins were staples in sideshows and circuses - realms of the displaced (30). Once again, Greenaway's films take white, European men and make them into the displaced and exotic Other. Their views on the world and on death as well as their own desire for symmetry put them at odds with other characters in the film as well as with the audience.

Displaced not by geography, but by class, Neville the draughtsman stands out from the very beginning of The Draughtsman's Contract in his difference from those around him. He does fall in line, however, with the patriarchal system that he steps into at the estate. As Douglas Keesey says of him, "[c]ompeting for ownership of the ladies and the land, of Mother Nature and of women as mothers who produce male heirs, Neville is as ruthlessly materialistic as his aristocratic 
rivals" (11-12). What he is missing, however, is the means to actually follow through; he does not have the money backing his aristocratic goals. Neville is stuck within the class in which he lives, and it shapes the way he views himself, just as society defines self-image in other areas such as sexuality. This class system also defines the way others view Neville, as the women view him as disposable. Greenaway inverts the norm which, Hall reminds us is that often women are viewed as the ones who are disposable (88).

Spica, the thief in The Cook, The Thief, His Wife, and Her Lover, has modern "aristocratic" goals. He, like Neville, is wildly materialistic and showy. However, unlike Neville, who can negotiate the classed space well, Spica cannot. His crude speech and willful ignorance exclude him from society. He creates the restaurant to exert his own control over it. The audience is made uncomfortable at how out of place he seems in such an environment. He is an Other in the world of his creation.

The men in $81 / 2$ Women are Others not only in public but, once they collect the women, in their own home as well. They are outnumbered and outsmarted by the women living under their roof. The women quickly begin to define what the men are and use any means necessary to gain power over them in order to escape. The men, like most of Greenaway's protagonists, are unaware of this manipulation; their arrogance does not allow them to see it, and this failure of vision results in the end in their financial destruction and the death of Phillip. 
Like these men and like Spica, Neville is trapped in his own box (stuck in his viewfinder). His own displaced subjectivity parallels that of the twins in A Zed and Two Noughts. Neville cannot interpret the things that he sees; he can only draw them. This problem dooms him: he sees things without trying to get any meaning from them. He is empty. Greenaway uses fixed shots, wide shots, very few close ups to establish the feeling of distance Neville creates for himself. Neville does not pick up on any of the nuances of a situation; he can only see the image from a distance.

Just as the women fight for their place in the patriarchy, Neville is forced to fight for his in the class structure; his subjectivity is written by the aristocrats. $\mathrm{He}$ seems at first to be an arrogant artist, full of himself and in control of all the situations he enters, but as the film progresses, we see that he is the outsider, that he cannot join the higher order. Greenaway says that Neville is frequently incorrect in his clothing, in his manner, and even in how to deal with others (Greenaway quoted in Keesey 20). This all indicates that he is the weaker subject, and though initially he appears to have the power of the patriarchy behind him, he drops down below even the women in the film in regard to power and control. As he is stripped of his clothing and killed at the end, he is completely helpless, in a reversal of the theoretical description of disposable women. Though the patriarchal conflict over "ladies and land" involves Neville, Keesey tells us he is less involved than he thinks (23). He is merely an observer and a victim; he has little control over what he observes, just as he has little 
control over what ends up in his drawings, and just as women are often described as having little control over their own lives within the patriarchal system. As Douglas Keesey suggests of the aristocracy,

This is not just a society that metes out proper punishment to the villain whom the detective has identified as a disturber of the peace. Rather, this is a society that punishes the detective to keep him from exposing the injustice inherent in its class structure; this is a community of murderers who kill the detective so that they can get back to homicidal business as usual (21).

Thus the film emphasizes even further the division of classes and the disposability of anyone who does not fit into the aristocratic world.

Another displaced observer Other appears in The Cook, The Thief, His Wife, and Her Lover. Amy Lawrence describes Michael as the most unassuming, "normal" -- if not boring -- looking character of the film, but he is notable because of his invisibility (169). He wears all brown, has brown hair, carries brown books, and quietly eats his meals. Whereas anywhere else, a character like this may simply blend in with the normal, Lawrence notes that he contrasts wildly with the tableau that surrounds him (182). She also says that the book lover falls "outside Spica's system where nourishment is inevitably transmuted into shit" (177). In fact, Michael is the only character who does not have a direct connection to Spica. Spica controls Georgina through marriage; Richard, the cook, is employed by him, as are all of the other kitchen workers. Spica's criminal cohorts are quasi-employees as well. Many of the other patrons of the kitchen are aligned with Spica and envy his power and control. 
Just as The Cook, the Thief, His Wife, and Her Lover, Baby of Mâcon addresses the issue of the subject displaced within his or her own world, and how startling it can be when one recognizes difference. Prince Cosimo Medici III, shown as a young man, views an onstage birth. When the baby in the play is born, Medici is shocked at the visceral nature of the child's birth. In fact he cannot accept immediately that he was born like the baby in the film, saying, "Are we really born like this? So naked, so wet, so covered in blood?" (Baby). He has been so sheltered in his aristocratic world that he is completely disconnected from the concept of a body and how it functions. Similarly, when invited to check the character known as "the Daughter" for an intact hymen, he looks and feels, but clearly does not know what to do and hurts her in the process.

Because he is already 17, Medici's childlike wonder throughout the film makes him look very foolish at times, but he feels and speaks through a noncynical lens. His sheltered existence allows him to see and feel things in a much more honest way than that of the older, more cynical characters. In the end, when he suggests the deflowering of the Daughter so she can be punished, since those in power cannot not execute her if she is a virgin, the audience can see that he enters the patriarchal system, but he does it as a way to avenge the child who has been killed. His sense of justice is skewed by the system in which he has been raised. The audience gets the idea that he does not understand the severity of his suggestion, and he once again seems disconnected from the body. 
Just as he maintains that the patriarchy hurts not only women, but men, Greenaway asserts that ideas of socioeconomic Othering within cultures and othering between cultures hurt all involved as well (see Ross 20 for a theoretical take on this sort of assertion). Greenaway shows that limiting the Other also stifles the subjectivity of the person trying to limit. He consistently argues that through accepting the Other the audience can grow and change for the better, and through this acceptance, we can help those trapped between two subject positions find their voices as well. Ideas challenging the western, white, and rich as dominant help the audience move outside of our limited worldview and show the benefits to both dominant and marginalized voices. In limiting themselves only to the subjectivity that is already known, people will not grow and change, and can be tempted to become bigoted toward Otherness. 


\section{CHAPTER 4: THE MONSTROUS, MUTANT, or MUTILATED OTHER}

In addition to breaking down the barriers and binaries of the patriarchy and sexuality, and of the idea of the foreign or displaced Other, Peter Greenaway tackles the idea of the monstrous, mutilated, and/or mutant Other, often inverting and undoing our ideas of what is monstrous and mutant, or challenging the boundaries between what is and is not monstrous. Sometimes the culturally expected monsters are not really monsters, and sometimes the "normal" become monsters, outlining how easily accessed the monstrous parts of all humanity are. He continues this line of argument through his films that turn the audience into monsters.

Almost no topic is off limits or taboo in his films, no matter how uncomfortable the audience will be, and Barbara Creed's list of "religious abominations" reads like a list of topics in Greenaway films: "sexual immorality and perversion; corporeal alteration, decay and death; human sacrifice; murder; the corpse; bodily wastes; the feminine body and incest" (46). While many of these items from Creed's list are addressed in his films, they are not placed in a typical horror setting; Greenaway is not generally classified as a horror film maker. 
Greenaway challenges or even simply ignores the barriers between the human and the inhuman ${ }^{13}$ in order to make his points: that all aspects of humanity are human and they should all be addressed on film, and that the audience's discomfort with these topics needs to be brought into the forefront and challenged rather than hidden. In a New York Times story in 1994, Greenaway relates an exchange with some horrified moviegoers who had booed his film. They said they suffered physical pain from watching it. He said to them "May I ask you why you go to the movies[?]" "To get a good, human message," was the reply. Greenaway's response was "Is that why you go? To have your prejudices massaged. That must be very boring" (Greenaway quoted in Shulman H18). The points he makes in this exchange are directly related to his exploration of the "monstrous, freakish Other" (Greenaway quoted in Shulman H 18) He presents images, narrative elements, and ideas that cause strong reactions in his audiences. Nadja Durbach explains that society categorizes "freaks" as such because they defy the categories society sets out. Applying this notion to Greenaway's work: mutants cross the boundaries Greenaway consistently challenges. Unstable bodies, described by Durbach as "both male and female, white and black, adult and child, and/or human and animal at the same time" occur frequently in Greenaway's films (3). There is not a dividing line in Greenaway's movies between the monstrous feminine and the monstrous masculine, the powerful and the vulnerable.

${ }^{13}$ Here, "inhuman" refers to either those viewed as non-human, even though they are physically human, or to the barbarism and cruelty of some of the characters. 
The audience, possibly thrown into crisis by the destruction of the boundaries between themselves and the abject Other described by Kristeva and Creed (Creed 64), may leave his films uncomfortable and feeling as though a part of the self has been challenged and even disrupted. Andrew Bennett and Nicholas Royle, in a chapter titled "Mutant," tell us, "the monster is excluded, abjected, not because it is entirely other but because it is at least in part identical with that by which it is excluded - with, in this case, the human" (260, emphasis in original). Greenaway's films align with this idea because they coax out and examine elements that reside hidden away in all of us in order to help the audience understand the ubiquity of the phenomena (260). Greenaway's intent is to not return the audience to a comfortable sense of division between the self and the Other. People quickly jump on the idea that if a film causes discomfort, or challenges their own ideas of the Other and challenges them to face that Other as an equal, then it must be a bad film. As a critic of $A$ Zed and Two Noughts said: "A film about rot is a rotten film" (Keesey 24). But is it?

\section{Undone Monsters}

Sometimes those that seem monsters in Greenaway's films are eventually exposed as never having been monsters or as changing from monstrous ways, and sometimes he shows pity for these monsters because they are, in fact, human. He discusses the monsters and their motivation, and makes the audience think about whether or not they themselves are contributing to Othering behaviors. 
Contact with corpses beyond necessary for burial is generally taboo in human societies, as an expression of the impulse to push away from death and rot, but Greenaway does not shirk from this topic. He recognizes that death and corpses are a part of humanity, and instead of being ignored, should be brought to the forefront and examined. He faces Creed's "ultimate in abjection" of the corpse in his films (65). Characters like the publisher in Greenaway films do not wall themselves off from corpses.

One initially monstrous character is the publisher in The Pillow Book. He does nothing good for anyone but himself throughout the film. He forces Nagiko's father into sex in exchange for the publication of his work, takes Nagiko's father's place in her life by drawing on her for her birthday, marries her to his abusive nephew, and sleeps with Jerome whom he loves so much that he breaks taboos and digs up and skins his corpse, throwing the rest of the body into a trash can, all of which is horrific in its own right. He becomes so obsessed with Nagiko's work that he is destroyed by his obsession. Blind to what Nagiko is doing, he allows her to manipulate him. In many ways, by the end, the monstrous becomes the victim, much as Spica does in The Cook, The Thief, His Wife, and Her Lover. The publisher is so pathetic by the end that the audience feels relief that Nagiko has him killed, but also pity for him that he was such a sad person that he put himself into that position. The pity the audience shows toward the publisher reinforces Greenaway's fairly consistent show of sympathy for the monsters in 
his films; they are human and need help rather than the punishment they often suffer.

Another type of the monstrous Other is the mutant. These monsters access "cultural anxieties" described by Nadja Durbach that are associated with deformation (174). Alba in A Zed and Two Noughts seems the most obvious of the mutant/mutilated: she is missing a leg (two by the end of the film). The twins in the same film, with their desire to return to the state of conjoined twins, fit into the category of mutant as well. Other mutants, or people who are mutilated, crop up often in his films. The deformed Mother in The Baby of Mâcon, shoved into a prison by the Daughter, is one example of a helpless mutant. She does not speak in the film at all; she gives birth to the beautiful baby and is hidden away and abused. Like mutants as described by Creed, she does not seem to be a part of the symbolic order; she herself seems pre-verbal (58). Another woman missing limbs is a member of the house in $81 / 2$ Women, but she is never described as monstrous. Greenaway challenges the audience expectation of the mutant by changing the boundary lines between mutant and "normal" - between the self and the Other. This destabilization of those boundaries creates anxiety in his audiences.

In A Zed and Two Noughts, Alba's divided subjectivity displays that she is both wrapped in the patriarchy with Van Meegeren and in direct opposition to it with the twins. She is, in many ways, an unstable subject. Many women want men to recognize their independence on one hand, but end up submitting to the 
patriarchal norms as they have been trained to do on the other; this tension because of male expectations throws women out of balance. This lack of balance comes through in Alba, who thinks she wishes to have her second leg amputated to make her body symmetrical and beautiful for men. She feels herself divided because of her lack of symmetry, but we are quickly shown that this sense of lack actually comes from the surgeon, Van Meegeren, who wishes to mutilate her further to have her conform to his idea of what she should be. Alba is even more trapped by Van Meegeren than she was when she lost her leg after the accident, but he convinces her that the amputation is the right thing to do, just as, according to feminist analyses, many women are convinced by the patriarchy to do what men want them do to.

The monstrous female Other is addressed in Drowning by Numbers -- or is it? Once again, Greenaway tells us that the stereotypes we have been conditioned to expect are incorrect. Cissie 1 drowns her husband in his bath. However, Cissie 1 symbolically rights the wrongs of the patriarchy, as Jake, her husband, has just drunkenly slept with a Sunday school teacher. Douglas Keesey describes Jake as an "emblem of the patriarchy" (62). To view the film as an allegorical purging of the patriarchy makes the women much less monstrous. It does not advocate a literal killing of men to punish them, but it encourages women to join together to rid the world of patriarchal systems. All three of the wives who drown their husbands can be seen in this light, as forces against the patriarchy to which they have been submitted. Through this purging of all of the 
different forces of the patriarchy, they heroically break free from it and the monstrous and unstable subjectivity they have been branded with.

Some might try to view the women in The Draughtsman's Contract as evil or monstrous as well, but they are using the patriarchal system (as the Cissies do) against the men who perpetuate it. According to the patriarchal system, they are fruit for the taking by the men in the film. They are merely property. According to the film, though, they are not merely fruit or property: they are subjects with the agency to right the wrongs of the patriarchy. Mrs. Herbert tells Neville the story of Ceres in the myth of Pluto and Persephone, and through this myth, the audience sees how women control fertility and reproduction (Draughtsman's). Without an heir to carry on the wealth, the women would have been out of the equation, and they would have lost their land, their shared home, and their positions in the class society. They control what they can in their own lives in spite of the men who are trying to set up rules to punish them simply for being women.

Albert Spica, the Thief in The Cook, the Thief, His Wife, and Her Lover who forces the man in the first scene to eat dog feces, has no redeeming social value. He is the absolute opposite of what most people strive to be. He is a monster. Greenaway actually considers this a failed character in many ways as, despite Spica's monstrosity, Greenaway finds women who say they would take him as a lover, and Greenaway reports audiences that say they can, in fact, "love to hate" him rather than just hating him until the very end of the film (Greenaway in Keesey 82). However, Spica, horrible as he is, serves a valuable purpose for 
the audience. As Keesey (83) suggests, in being attracted to a vile character such as Spica, we of the audience are reminded of our own darker and rebellious nature. In our siding with him, on any level, parts of humanity that normally remain locked away are brought to the surface and offered for thoughtful consideration. Most people would deny such attributes even exist within their own psyches, but Greenaway skirts toward sympathy for Spica at points in the film, humanizing him just before his death, thus strengthening the idea that there are parts of him that each of us can identify with. Actively ignoring this monstrosity can allow people to be blind to it in their own lives.

Ultimately the tables turn completely, so to speak, on Spica. He becomes the Other to those in the film. Michael has his books to make his life rich and complete his personality. Richard has his cooking to make him a complete person. Georgina, who breaks free from Spica and finds her own personality with the help of Michael, is well on her way to becoming a full person by the end of the film. Greenaway himself says of her: "she finds the strength and vocabulary to create a rebellion and finally destroy the husband" (Greenaway quoted in Indiana 121). Greenaway says that Spica, however, has no center; he has no purpose in his life (Greenaway in Siegel 25). There is nothing that he is passionate about in more than a superficial or wrong way. He treats Georgina poorly, does not understand food, and actively ignores books. His self-worth is tied mostly to his wealth, which the film indicates is not a viable life-fulfilling pleasure. At the end of the film, the cooked body of Michael physically separates Spica from the rest of 
the cast. All, audience included, stare down at Spica on his knees in this scene. He has become the Other faced with destruction by the marginalized voices he has abused throughout the film. Typically, we would expect that the monster is going to be defeated and order will be restored. This movie, however, tells us a restoration of order will not happen. Keesey notes that Georgina does not produce children, as nearly all of Greenaway's heroines do. Instead of creating life, "she brings forth death, making Michael's love into a reason to kill Spica, feeding her [l]over's spirit to her husband as mortal flesh" (99). He reminds us that the final taboo act of forced cannibalism, often mentioned in scholarship and reviews, is meant to shock the audience. However, the viewer may sympathize with Georgina, and Keesey suggests that the loss of her conscience can be viewed as tragic (125). Has the monster been vanquished, or has he infected everyone else around him in the film with his monstrosity? Georgina is now a murderer, and all of the people surrounding her while she becomes one are as culpable as she is. We, as the audience, initially feel as though justice has been done. The question remains, however, whether or not Spica's death solves the problem. Greenaway does not seek to answer the question directly; he says that the film is "a venture into those areas of least avowable obsession that frighten, dismay, shock and disgust us, but which we very well know haunt us all" (Greenaway quoted in Rodgers 221). He reminds us that we need to be aware of these monstrous parts of ourselves in order to keep them in check. To deny they exist may allow them to take us over and turn us into the monstrous. After we 
side with Georgina at the end, we can see in reflection how monstrous we have become, grateful for a murder.

\section{Othered Monsters}

Georgina's shift to the monstrous while Spica moves away from it is a dual example of Greenaway's bending and breaking of boundaries and binaries. While one set of monsters in Greenaway's films are undone, humanized, or shown through a different lens as not having been monsters at all, some characters begin as stable subjects and then through their behavior become monsters in the eyes of the film.

The twins in A Zed and Two Noughts become obsessed with the wives' deaths and the decay of their bodies. The men's obsession with death kills them, but Greenaway does not present their deaths as tragic. They fulfill their own desires to become corpses themselves and to teach how decay happens. Douglas Keesey tells us of the monstrosity of the twins in A Zed and Two Noughts in that they create death instead of containing it through their study of death, and that they are so destabilized by their obsession with the deaths of their wives and ultimately their own deaths that the obsession separates them, and ultimately drives them to suicide (36). The twins are some of the more monstrous characters in the film, but at the same time some of the most vulnerable, as they fall victim to exactly the structure they wish to contain. In their 
scientific study of death and decay, they hope to understand them in order to conquer them. As shown previously, the attempts by the characters in The Draughtsman's Contract and Drowning by Numbers to control their surroundings through their created structures are similarly unsuccessful endeavors, as Greenaway indicates in an interview. The twins are no different from his previous characters. As Greenaway says, they "wish -against all odds-to create a rational view of the world out of all its chaotic parts. However the structures and controls are always mocked as being inadequate or ineffectual or destructive" (Greenaway in Hacker and Price 190). Through trying to control death, they actually seem to emanate death from within, and they suddenly find death all around them, which is the opposite of their intention. They become so unnatural that they kill themselves, and try to document it through an automatic camera system. The men lie on a board of the same kind they had used to study death in their lives, and as night falls, the board, the men, and the camera system are covered in snails. The snails short out the system, and the death and decay the men wished to record are disrupted by nature; they can control neither nature nor their own deaths in the way they wish. The brothers began the film as stable subjects and are quickly thrown into chaos by the deaths of their wives. As the film progresses, instead of maintaining their subjectivity through normal grieving, they move toward the monstrous Other, breaking down the barriers between life and death. 
While Greenaway shows the men in Drowning by Numbers as failures relative to the patriarchy's objectives, Mio, the drowned Geisha in $81 / 2$ Women, is a metaphor for the patriarchy washing its hands of responsibility for the destruction of women throughout history. Stripped of her identity and marginalized until her only option is suicide, Mio drowns herself, and the men cannot figure out why. They blame it on the loss of her shoes (another ugly stereotype: that a woman might kill herself because she lost her shoes), when in reality, as Keesey suggests, her death is the result of the removal of all her possibilities for escape, figured by her shoes. With her last shred of hope removed, Mio has become a woman whom men within the patriarchy seek out as ideal, and who is no longer alive figuratively, so she removes herself physically as well. Their anger at her death shows how ignorant they are of reality and how much empathy they lack (186-187). Their subjection of her, and their failure to comprehend the reasons for her abjection (by suicide), make them monstrous.

The murderous monstrous characters in The Draughtsman's Contract are never directly revealed, leaving the possibility that everyone except Neville has become monstrous in that they are all potentially responsible for the death of Mr. Herbert and ultimately Neville as well. While they all seem to be (somewhat) stable subjects as the film progresses, the audience must make decisions about the morality and monstrosity of all the characters, as well as about which characters are responsible for the murder. Greenaway says that all the characters' malice is his main focus in the film (Greenaway in Rowe 233). 
Throughout the film, the audience sees what Neville sees, and knows only the same things he knows. We expect a grand reveal of the murderers to Neville, or at the very least the audience, as is typical in a murder mystery; an audience expects the social order to be upheld and for the "bad guy" to be punished. This is not the case with Neville or this film. His blindness to the social situations he finds himself in and his ultimate murder at the hands of those who accuse him of murdering Mr. Herbert outline the injustice that can happen within a political system, because Neville is willing to ignore the position they put him in as the outsider and to go along with their structured hierarchy in order to make money. Keesey reminds us that everyone involved in the patriarchal-capitalist system in this film becomes evil in one way or another, reinforcing the monstrosity of the system (19). This Othering of those who are typically viewed as the stable subjects inverts the norms and breaks down the boundaries between the "normal" and the monstrous.

Greenaway frequently exposes his audience to the role of the monstrous Other. The Baby of Mâcon makes our monstrosity its overall topic, and challenges us to look at ourselves as monstrous. In it, Greenaway questions the entertainment value of gratuitous sex and violence. People lodge the complaint against Greenaway that he uses gratuitous sex and violence in his films, but one can argue that his representations of these things are thought-provoking (not gratuitous), that they challenge the audience's notions of good and bad, whereas films that are purely for entertainment and include excessive sex and violence 
may harm the audience. One of the arguments The Baby of Mâcon makes is that other films have created monstrous audiences, hungry for blood and sex.

The film includes an intricate, ever-expanding pattern of concentric circles of audiences, almost like nesting dolls. The actors are playing audience members through five levels of audiences, and the circles end only with the film's audience (or there may even be a sixth audience, a higher power viewing us). Understanding the different levels of the plays/audiences is important in understanding the film's meanings. When watching the film, the audience of the film does not get a clear view of all these audiences until the very end, nor are all the players directly aware of all the other audiences. All this creates a sense of confusion that makes the audience of the film ask what things are "happening" and which are parts of plays (they all are, but how "real" is the action in each level?) Does it make it all right that we see sex and violence as parts of plays or movies, though if we saw them in real life we would be horrified? Should we not, as viewers, be as horrified to see them portrayed on the screen?

The different levels of plays/audiences are as follows:

1. The Christ story (the center; the players are not playing an audience but a group of people experiencing a "real" event).

2. The story of the town of Mâcon, facing a plague, in which story a child is (maybe) born to a woman claiming to be a virgin. The actors portray the people of Mâcon watching the play of the Christ story. 
3. Actors portray seventeenth century Italians who are watching actors playing the people of Mâcon (who are watching the actors playing the Christ story.) Their story is one of reactions and taking part in the play they are watching.

4. Another audience, whose location and time period are not known, are revealed by the pulling back a curtain at the end. They watch the other three levels, but are invisible to the film audience until the end.

5. The film audience. We try to take in all the action, though we are confused until clarity is given at the end as the curtains are pulled back and the audiences/actors all take their bows.

6. Greenaway suggests on the cover of one DVD version that the final audience is God watching us (Greenaway in Keesey 126).

The levels of discomfort and confusion for the audience intensify through the film, reaching the point of extremity with the repeated rape of the Daughter, resulting in her death. The scene of rape is depicted within the second/third level of the actors. The Daughter is being played on the second level stage (as a member of the audience in Mâcon,) but when the "soldiers" say they are really going to rape the actress playing the Daughter, not just pretend to do so, the film audience may gasp as the boundaries between the plays and audiences are ruptured, throwing the subjectivity of everyone involved into a state of anxiety. Why is it not as shocking for the character in the second level to be raped? When the audience steps back another level, the act becomes more "real" even if this 
realness is an artifice. Where is the line of appropriateness? Hollywood films

erase the immorality of enjoying the violence they portray. The audience

commonly feels it has no reason to feel guilty. Greenaway's point in this film is

that the audience should not be voyeuristic in enjoying scenes of sex and

violence. Most would agree it would be monstrous to watch real murder, real

rape, or real torture. Greenaway says:

The last scene, audiences watching audiences watching audiences watching audiences is intended to make a bond of identification with the audience in the cinema. Like the language of visual and moral sensation of the Baroque era the film invokes, the film works on the watcher to make him a participant, so maybe that was deeply unsettling. . . [The film shows] actors playing actors in a drama so patently a costume drama that they change their costumes three times in full view of actors playing an audience. The disturbance of the suspension of disbelief occurs again and again throughout the film, most provocatively in the rape scene, when identification of character, actress, play acting, and crime are thrown into painful confusion (Greenaway quoted in Woods 277).

The audience should not be "off the hook" for what they enjoy on the screen. Pulled between the "realities" in the film, Greenaway's audience is made to feel quite guilty about what is depicted. We feel as though we are monsters for enjoying the types of entertainment common in our society today - graphic sex and violence. We do not want to admit that we ourselves have become monsters for our enjoyment of these films, nor the societal effect this has on the subjectivity of all members of society.

The prince in the third level of the plays illustrates the struggle with the suspension of disbelief of different audiences; when faced with the death of the 
child, he is inconsolable, but is told what he is seeing is not real, it is "just a play - with music" (Baby). The audience writes off his reaction as hysterical because it is only a play, just as the film itself is only a film. Keesey says that "Greenaway disturbs the boundary [between audience and actor,] causing us to reexamine our motives as viewers, our connection with characters, and the relations of film violence to reality" (127). Should the audience accept what is seen on film as "only a movie?" Would the audience be better served by film if they would investigate it as Greenaway does, as a way to challenge viewpoints and to think in a new way about a topic? This kind of thinking allows the viewer to grow and change rather than to walk out of the theater exactly the same person as when he or she entered. The encounter with the Other within ourselves helps to break down those barriers that have been set up by society to fit people into nice, neat categories, thereby allowing us to make value judgments about people, and to feel superior to what we view as the Other. The encounter destabilizes our views on what a stable subject might consist of.

The audience in the movie theatre feels the horror when the audience at the funeral becomes monstrous as they dismember the dead child ritualistically to satisfy their religious needs. In addition, the Church and the Daughter have both fallen into the monstrous-feminine role Creed describes by refusing to let go of the child; they both depend upon the child for their own needs (50). The Church is certainly a monstrous character throughout the film, as the need for a miracle to rescue the town from pestilence creates a frenzy that perpetuates the idea of 
human sacrifice as a way to atone for sins. The examination of the taboo of human sacrifice through the ritualized setting of the Church sheds light upon an area of humanity not normally addressed in a filmic setting outside the horror genre.

Another monster is Prospero in Prospero's Books. Prospero, defined by Shakespeare as heroic and hegemonic, becomes an Other in Greenaway's film. Prospero defines Caliban as a devil, as his opposite, since he views himself as good. This definition must be upheld for Prospero to maintain his own elevated image of himself, and his own dark side must continue to be projected onto Caliban. It is, however, Prospero himself who is monstrous in his treatment of Caliban and of the other natives on the island, enslaving them. In order to keep his colonizing power, Prospero must keep Caliban believing that he is inferior to Prospero, for if the island were to rise up, Prospero's power would quickly be lost.

Prospero's walk through his library at the beginning of the film shows many characters from mythology, which is, according to Creed, "populated with gendered monsters" (46). "Monsters" are present to show the audience where Prospero's ideas of the monstrous versus the "normal" and "pure" come from. The Renaissance ideas of monsters come from earlier times, once again supporting Greenaway's indictment of all of cultural history in its establishment of boundaries, binaries, and dichotomies against which he speaks in his films. Prospero himself perpetuates the Othering through his voicing and manipulating all the characters in the film. His cruel and inhumane treatment of Caliban, 
especially, demonstrates this, as Caliban is his tortured slave. Moreover, Prospero treats Miranda as a commodity to be traded for his own return to the social order he desires to be in.

Greenaway's ideas of the monstrous, like his ideas about the gendered Other and the displaced Other, fit into a cohesive world view that binaries and boundaries that define people into hierarchical categories are wrong and must be challenged and undone, to make room for an order with equity for all. The systems he challenges elevate those who should not be elevated, and they marginalize and abuse those who are undeserving of such treatment. His treatment of ideologies and dividing lines between people is consistent through his body of feature work. He pushes the mutant Other into the forefront and challenges his audiences to grapple with it. While many consider his corpus challenging and many have attacked it as incoherent and "too intellectual," his statements on societal discrimination are insightful and dovetail with theories seeking recognition, understanding, and acceptance. 


\section{CONCLUSION}

Peter Greenaway is still making films. In fact, according to his personal social media entries, he just finished principal filming on his next film called Eisenstein in Guanajuato, and he has three other scripts in various stages of development (radioakt). His 2012 film, Goltzius and the Pelican Company, is still unavailable in DVD form, but is being shown in special exhibitions throughout Europe. Last May, the French Cultural Ministry awarded him the medal of Commander of Arts and Letters. In October of 2012, he received the Stockholm Film Festival's Visionary Award (Associated Press). The British Academy of Film and Television (BAFTA) honored him in October 2013 for his outstanding contribution to British film (Beaumont-Thomas).

During the presentation at the BAFTA Awards, actress Juilet Stevenson recalls the miserable things Greenaway asked her to do during the filming of Drowning by Numbers. Following, however, is a passionate description of Greenaway as "visionary and inspirational," and of his films as having "beauty and invention" (Stevenson in Beaumont-Thomas). His nearly constant speaking engagement schedule, the continued funding for films, and his art installations all over Europe speak the message his films continue to bring to the world. In breaking down the boundaries between traditional visual art and film, Greenaway's boundary-breaking attitude extends far beyond the external, 
physical divisions, but also dissolves and restructures the internal boundaries we have been culturally conditioned to hold.

It is important to continue to analyze, investigate and describe these boundaries in order to break them down. Greenaway's work breaks down the boundaries of gender, race, and monstrosity. Many people are confused by his work and want to confront Greenaway himself as a character rather than investigating the work, an attitude that may speak to the effectiveness of one of Greenaway's own theories. He says that he wishes for an audience to "make direct contact with the imagination of the filmmaker" (Greenaway quoted in Matthews). In engaging with his filmic work, however, we can move beyond the character of Greenaway and move into the character of ourselves, and we can move beyond engaging with film purely as entertainment and allow it to help us redefine our worldview. In revisiting his work through the lens of theories of Otherness and the inclusion of these themes in his narrative work, we are reminded of the power people have to change their own views in order to empower themselves - or to realize how to help marginalized voices gain the power they need to fight against the dominant voices in society wishing to keep them marginalized.

Greenaway's work is complex and beautiful, and often difficult to view because our own subjectivity is prodded and questioned as we watch his films. Generating strong emotional reactions, both positive and negative, Greenaway's disruption of the boundaries that divide people continues to be relevant and 
thought-provoking today, even as his first narrative film was when it was released over three decades ago. 


\section{REFERENCES}

Aalito, liris, and Albert J. Mills, eds. Gender, Identity, and the Culture of Organizations. New York, Routledge, 2002. Print.

Associated Press. "Filmmaker Peter Greenaway Wins Stockholm Film Festival

Visionary Award." CTV News. CTV News, 22 Oct. 2013. Web 6 Apr. 2014.

Beaumont-Thomas, Ben. "Baftas 2014: Peter Greenaway Wins Outstanding Contribution Award." The Guardian. The Guardian, 16 Feb. 2014. Web. 6 Apr. 2014.

Bennett, Andrew and Nicholas Royle, An Introduction to Literature, Criticism and Theory. Edinburgh: Pearson, 2009. Print.

Berlant, Lauren and Michael Warner. "What Does Queer Theory Teach Us About X?" PMLA 110, no 3 (1993): 343-349. Print.

-----. "Sex in Public." Publics and Counterpublics. New York: Zone, 2002. 187208. Print.

Brinkler-Gabler, Gisela, ed. Encountering the Other(s): Studies in Literature, History, and Culture. Albany: State University of New York Press, 1995. Print.

Butler, Judith, John Guillory, and Kendall Thomas, eds. What's Left of Theory?: New Work on the Politics of Literary Theory. New York: Routledge, 2000. Print. 
Creed, Barbara. "Horror and the Monstrous-Feminine: An Imaginary Abjection" Screen 27, no 1 (1986): 51. Print.

Desmond, William. Art, Origins, Otherness: Between Philosophy and Art. Albany: State University of New York Press, 2003. Print.

-----. Desire, Dialectic, and Otherness: Essay on Origins. New Haven: Yale University Press, 1987. Print.

"Peter Greenaway." Dis Voir: Books on Contemporary Culture. Dis Voir, n.d. Web. 6 Apr. 2014.

Doane, Mary Ann. Femmes Fatales: Feminism, Film Theory, Psychoanalysis. New York: Routledge, 1991. Print.

Durbach, Nadja. Spectacle of Deformity: Freak Shows and the Modern British Culture. Berkley: University of California Press, 2010. Print.

Greenaway, Peter, dir. 8 1/2 Women. Perf. John Standing, Matthew Delamere, Amanda Plummer, and Vivian Wu. Universal, 2000. DVD.

---. The Baby of Mâcon. Perf. Julia Ormond, Ralph Fiennes, and Phillip Stone. Film4 Library, 2011. DVD.

---. The Belly of an Architect. Perf. Brian Dennehy, Chloe Webb, and Lambert Wilson. MGM, 2004. DVD.

---. The Cook, the Thief, His Wife, and Her Lover. Perf. Richard Bohringer, Michael Gambon, and Helen Mirren. Starz, 2001.

---. The Draughtsman's Contract. Perf. Anthony Higgins, Janet Suzman, and Anne-Louise Lambert. Zeitgeist, 2008. DVD.

---. Drowning by Numbers. Perf. Joan Plowright, Juliet Stevenson, and Joely 
Richardson. Film 4 Library, 2012. DVD.

---. Nightwatching. Perf. Martin Freeman, Emily Holmes, and Eva Birthistle. E1 Entertainment, 2009. DVD.

---. The Pillow Book. Perf. Vivian Wu, Ewan McGregor, and Yoshi Oida. Sony, 1996. DVD.

---. Prospero's Books. Perf. John Gielgud, Michael Clark, and Michel Blanc. AAE Films, 2009. DVD.

---. A Zed and Two Noughts. Perf. Andréa Ferréol, Brian Deacon, and Eric Deacon. Zeitgeist, 2008. DVD.

Hacker, Jonathan, and David Price. Take Ten: Contemporary British Film Directors. Oxford: Clarendon, 1991. Print.

Hawthorne, Christopher, "Flesh and Ink." Salon 6 June 1997. Web. 8 Sept 2013. Hall, Donald E. Queer Theories. New York: Palgrave Macmillian, 2003. Print.

Harris, Melissa, ed. Aperture: The Body in Question. New York: Aperture, 1990. Print.

Indiana, Gary, "Peter Greenaway." Interview 20 (March 1990): 120-122. Print. James, Nick. "Body Talk." Sight and Sound 6, no 11 (1996): 14-17. Print.

Keesey, Douglas. The Films of Peter Greenaway: Sex, Death and Provocation. Jefferson: McFarland, 2006. Print.

Kristeva, Julia. Powers of Horror: An Essay on Abjection, trans. Leon S. Roudiez. New York: Columbia University Press, 1982. Print.

----. Strangers to Ourselves. Translated by Leon S. Roudiez. New York: Columbia University Press, 1991. Print. 
Lawrence, Amy. The Films of Peter Greenaway. Cambridge: Cambridge University Press, 1997. Print.

Melia, Paul, and Alan Woods. Peter Greenaway: Artworks 63-98. Manchester: Manchester University Press, 1998. Print.

Prasad, Anshuman, and Pushkala Prasad "Identity and Difference in the New Globalized Organizational Landscape." Aalito, liris, and Albert J. Mills, eds. Gender, Identity, and the Culture of Organizations. New York, Routledge, 2002. 57-71. Print.

Rodgers, Marlene. "Food and Defilement in Peter Greenaway's The Cook, The Thief, His Wife, and Her Lover." Descant 22, no 1 (1991): 215-224. Print. Ross, Stephen David. "What of Others? Whose Subjection?" Encountering the Other(s): Studies in Literature, History, and Culture Ed. Gisela BrinklerGabler. Albany: State University of New York Press, 1995: 19-34. Print. Said, Edward W. Orientalism. New York: Random House, 1979. Print. Schwab, Gabriele. The Mirror and the Killer-Queen: Otherness in Literary Language. Bloomington: Indiana University Press, 1996. Print.

Shulman, Ken. "Peter Greenaway Defends his ‘Baby." New York Times. 6 Feb. 1994: H18. Print.

Siegel, Janice F. "Peter Greenaway's The Cook, The Thief, His Wife, and Her Lover: A Cockney Procne." Classical Myth and Culture in the Cinema. Ed. Martin M. Winkler. Oxford: Oxford University Press (2001): 233-257. Print. Siegel, Joel. "Greenaway by the Numbers." Washington City Paper (6 Apr 1990): 
18-26. Print.

Stacey, Jackie and Sarah Street, eds. Queer Screen: A Screen Reader. New York: Routledge, 2007. Print.

Steinmetz, Leon, and Peter Greenaway. The World of Peter Greenaway. Boston: Journey Editions, 1995. Print.

Warner, Michael. Publics and Counterpublics. New York: Zone, 2002. Print. Woods, Alan. Being Naked, Playing Dead: The Art of Peter Greenaway. New York: St. Martin's, 1996. Print. 


\section{CURRICULUM VITA}

NAME: $\quad$ Kristina Sue Bohleber Groves

ADDRESS: $\quad 3605$ Adobe St.

Evansville, IN 47720

DOB: $\quad$ Evansville, Indiana - November 30, 1978

EDUCATION

\& TRAINING:

B.A. English

University of Southern Indiana

1997-2001

INVITED PRESENTATIONS:

Paper Presentation: "Her Eyes Were Watching the World"

Butler Undergraduate Research Conference 1999

Paper Presentation: "World War II Evansville: Two Interviews"

RISC Symposium (now Endeavor! Symposium) 2001

Co-Writer: "It's a Scandal, It's an Outrage: Who's Buried in Bosse's Tomb?"

Reitz Home Museum Mystery Event Play 2008

Guest Lecturer: "Tutoring ESL Writing Students"

University of Evansville 2011

Guest Speaker: "Friday Night in the Forum Film Series"

University of Southern Indiana 2012

Radio Interview: "English as a Second Language"

The Trend WNIN Evansville 2013

Paper Presentation: "Rhetoric: The Missing Piece" Indiana College English Association Conference 2013

Guest Speaker: "Friday Night in the Forum Film Series"

University of Southern Indiana 2013 